\title{
ЕТНІЧНІ ОСОБЛИВОСТІ АРХЕТИПУ ГЕРОЯ В СЛОВ'ЯНСЬКІЙ КУЛЬТУРІ
}

УДК: 159.9.016.1

\section{Васюк Катерина Миколаӥвна}

Кандидат психологічних наук, доцент, доцент кафедри психології Донецького національного університету імені Василя Стуса м. Вінниия (Украӥна)

\begin{abstract}
Анотація. В статті здійснений аналіз уявлень про геройчну поведінку в слов'янській культурній традищіi. Виділені основні характеристики образу Героя і простежений його генезис від феномену богатирства до козацтва як матеріальне втілення в епосі архетипу колективного несвідомого. Проаналізовані спільні та відмінні риси у представлені архетипу Героя в західноєвропейській та слов'янській традиціях. Доведено, щзо слов'янська культурна традиція має специфічні риси у визначення образу Героя, зокрема, виділені шість базових рис Героя. Також здійснене порівняння основних рис слов 'янської та західної традиції, в результаті чого визначено, щуо слов'янський архетип більш реалістичний, має не тільки позитивні, а й негативні риси.
\end{abstract}

Ключові слова: архетип, Герой, культурна традиція, подвиг.

Постановка проблеми. Слов'янська культура $є$ одною 3 найдавніших у світовій історії. Сучасна українська культурна традиція як пряма спадкоємиця загальнослов'янської багато чого запозичила з неї. Кожен індивід, розвиваючись в певних культурноісторичних умовах несвідомо переймає базові уявлення про світ саме зі своєї культурної традиції. Звідси походять ідеали, ціннісні орієнтації, переконання і світогляд людини в цілому, навіть психологічні проблеми окремої особистості в суті своїй грунтуються на загальних етнічних традиціях. Образ героя для кожного етносу має загальні риси 3 іншими етносами, але в той же час містить і унікальні характеристики, які складалися під впливом історичних подій, особливо негативних (війни, революції, зміни релігій, форми правління тощо).

В негативні періоди розвитку суспільства людям потрібні були орієнтири і позитивні образи, які б слугували точкою опори, давали наснагу боротися с труднощами. Саме тому образ Героя можна вважати вічним. Він існуватиме допоки існує етнос. Герой - це своєрідний еталон позитивної, суспільно схва- 
льної поведінки, до якої потрібно прагнути просоціально налаштованим людям або взірці поведінки, які недосяжні для більшості і тому викликають повагу і вражають уяву простої людини.

На жаль, тема героїзму в психологічній науці підіймається вкрай рідко. В основному дослідження проводились в межах філософських культурологічних або соціологічних досліджень. В основному, підіймалися питання визначення ознак Героя та класифікації їх типів. Найбільш відомим систематизатором, наприклад, є В.Д. Плахов. На сьогодні психологічна наука майже не займається питаннями мотивації героїчної поведінки, вивченням механізму іiі прояву і чинників, які впливають на виникнення здатності до героїзму.

3 культурологічних досліджень стає зрозумілим, що героїчні риси, які вважаються типовими, мають культурну специфічність, тобто в різних культурах і країнах можуть бути відмінності в наборі рис, які визначають поведінку людини як героїчну, а національні Герої мають ті риси, які з давніх часів були шанованими в певній культурі.

Мета нашого дослідження - виявити специфічні для слов'янської культури психологічні риси героїв, які обумовлюють сучасне сприйняття і оцінку поведінки особистості як героїчної.

Об’скт дослідження - архетип Героя.

Предмет дослідження - етнічні особливості архетипу Героя у слов’ян.
Гіпотеза дослідження полягає у припущенні, що архетипні уявлення про героїв у слов'янській традиції мають свої специфічні риси, відмінні від інших етносів, і обумовлюють інтерпретацію поведінки як героїчної на сучасному етапі розвитку суспільства.

В якості методів дослідження використовувався змістовний аналіз давньослов'янських дум і переказів про героїв, в тому числі і контент-аналіз, а також порівняльний аналіз виділених поведінкових патернів і особистісних рис в образі героя з рисами особистості і особливостями подвигу сучасних героїв.

Ідея існування таких загальнокультурних образів нова в психології. Вперше це поняття грунтовно розглянув К. Г. Юнг у своєму вченні про архетипи. Він визначав їх як своєрідні установки і готовність до сприйняття інформації певним чином, які виражають потребу людей у інформації. Вони успадковуються генетично незалежно від культури, статі, інтелектуального рівня і інших особистісних та соціально-демографічних характеристик особистості. Індивідуальність людини проявляється в тому, яке смислове образне наповнення отримує той чи інший архетип, а також рівень впливу його на повсякденну поведінку індивіда. Оскільки архетипи в структурі особистості вибудовуються в ієрархію, так звану Самість. Базова стратегія поведінки керується в першу чергу тими архетипами, які знаходяться на головних позиціях в цій ієрархії [4]. Серед загально відомих архетипів, на- 
приклад Аніма-анімус, Тінь, Персона, Самість $\epsilon$ також і архетип Героя. Він має свої типові риси, які взагалі не залежать від культурного середовища. Дж. Кемпбелл назвав ці риси «мономіф». В його основі лежить незмінний сюжет і декілька допоміжних персонажів, які допомагають підкреслити і виявити важливі психічні риси Героя. Основні компоненти моно міфу: початок становлення, коли Герой зустрічає Вчителя або Провокатора на подвиги, дорога випробувань і зустріч з Ворогом. Іноді такі зустрічі трапляються не один раз. Здійснення головного Подвигу. Також є Друг або Помічник, часто є Кохана, заради спасіння або завоювання прихильності якої і здійснюються подвиги.

На думку Дж. Кемпбелла, цей сюжет відображає процес становлення Его, а також містить інтригу, тому він не втрачає своєї актуальності протягом тисячоліть, хоча переказується в різних інтерпретаціях багато сотень разів. Привабливість героїчних оповідань в тому, що Герой протягом історії розвивається, долає власні слабкості. В принципі, те ж саме відбувається в сучасному світі. Героїчна поведінка передбачає долання внутрішніх страхів і сумнівів, що дає небачене зростання особистості протягом короткого часу. Після скоєння подвигу особистість вже ніколи не буде такою, як раніше, за допомогою цього суб'єкт підіймається над більшістю. Герой не може залишитись непоміченим, навіть якщо його імені не знають, розголос про його подвиг піде в народі [1].

Кожен етнос обирав власний спосіб вираження архетипів. Як правило, це епос, наприклад, в Давній Греції він носив форму міфу, у слов'ян - билина. На жаль, психологічних досліджень з цієї тематики практично немає. Проблемою образу героя займаються в основному в філософських та культурологічних дослідженнях. Але елементи психологічних знань там все ж таки є. В фольклористиці можливо почерпнути дані щодо особистісних рис героїв та скласти їх типовий психологічний портрет, що буде придатним для порівняння з сучасними героями вже як з реальними, а не наполовину міфологізованими особистостями.

Неоціненними джерелами в дослідженні цієї проблеми є праці О. Потебні, В. Проппа та С. Орлова. Вперше ж проблему образу героя в мистецтві поставив М. Рєріх. Вивчаючи історію культури, він акцентував увагу на універсальних цінностях нації, які існують поза часом і успадковуються наступними поколіннями завдяки привабливому образу героя. Також це $є$ потужним виховним засобом для молодого покоління, тому владні структури часто намагаються маніпулювати виховним процесом, штучно спотворюючи образи вже існуючих героїв або вводячи нових [3].

Л. В. Шапошнікова пояснює таку стійкість існування образу героя тим, що цей архетип у поверхневій, про соціальній формі своїй 
здатен еволюціонувати, легко підлаштовується під різний тип мислення: міфологічне, релігійне, наукове. Архетип героя включається в мета-історичний процес, тобто це атрибут еволюції цивілізації в цілому і актуальне відображення цієї еволюції. Тому герої являються своєрідними взірцями в еволюційному процеci, орієнтирами і джерелами для натхнення: «якщо хтось зміг, чому я не зможу».

Герої породжують нових героїв і цей процес не зупиняється ніколи. Цей механізм широко використовується в суспільствах для виховання підростаючого покоління. Але, на жаль, цей механізм часто використовується провладними структурами, правлячими класами в корисливих цілях, пропаганді і просуванні потрібних ідеалів.

Як приклад, Герой Радянського союзу льотчик-винищувач О. Маресьєв, який зміг літати без обох ніг, спочатку теж не вірив у свої сили і повірив в себе лише після того, як прочитав статтю в газеті про льотчика часів Першої світової війни, який літав без ступні. Саме тому глибинний сенс існування такого архетипу - моральне виховання молоді. Але якість цього виховання вже залежить від конкретного втілення в суспільній свідомості (спонтанному чи спеціально створеному) образу національного Героя.

I. М. Суравньова вирізняє локального і загальносуспільного героя. На нашу думку, в актуальний момент особистість, яка здійснила подвиг може претендувати лише на роль лока- льного Героя [3]. До цього типу також належать ті, хто проявив героїзм на шляху духовного самовдосконалення, а не захисту інших. Загальний Герой - це поняття ретроспективне. На цю роль претендують особистості, які мають загальнонаціональне визнання. Причини цього не завжди у виключності їх подвигів, а в тому, що ці особистості є носіями дійсних або тих, що приписуються їм, рис особистості, які в даній суспільній групі визнаються за ідеал. На жаль, дуже часто пропаганда провладних структур штучно створює ці образи для маніпуляції свідомістю мас, що є досить ефективним засобом впливу на суспільну думку і контролює в певній мірі процес виховання молоді.

Але навіть при такому раціоналістському підході базові компоненти образу Героя залишають на несвідомому рівні. Переважна більшість людей не зможе пояснити, чому той чи інший персонаж чи подвиг його викликає в них універсальні емоції.

В буденному розмінні герой - це здійснення видатних за своїм суспільним значенням дій, які вимагають від людини особливої мужності та здатності до самопожертви. Повертаючись до теми архетипу Героя у слов'янській традиції варто виділити основні ознаки героїчної поведінки, спираючись на традиції В. Г. Бєлінського:

Це готовність вийти за межі своїх звичайних можливостей у своєму прагненні допомогти іншим, врятувати їх від біди в фізично- 
му і духовному сенсі.

Здатність зрозуміти і прийняти позицію іншого, не обмежуватись тільки власним сприйняттям дійсності, висловлювати повагу до чужих цінностей, навіть якщо вони розходяться $з$ його власними.

Обмеження задоволення власних потреб, принесення їх в жертву іншим, справі. Але це не просто звичайна форма мазохізму. Така самодепривація - це засіб досягнення найвищої життєвої мети, яку герой вважає важливою для себе.

Здатність взяти на себе відповідальність за долі інших людей

Створювати власні ідеали і протистояти моральному тиску загальноприйнятих авторитетів.

Особистісна цілісність, вірність ідеям, здатність встановлювати високі стосунки в коханні і дружбі [1].

3 огляду на ці ознаки, вимальовується такий ідеальний портрет, який не може бути втілений в реальній людині з усіма ії недоліками, але ці ознаки не обов'язково повинні зустрічатися всі і одразу. Вони можуть розвиватися протягом тривалого часу або зустрічатися частково, по принципу більшості. Якщо порівняти ці сучасні погляди на героїчну поведінку зі стародавніми уявленнями про героя в слов'янській культурі, то згідно з нашою гіпотезою, вони повинні співпадати, оскільки архетип в основі своїй інертний. Сучасні ознаки безперечно мали витоки в стародавніх тради- ціях. Основним джерелом інформації для нас являється народний епос.

В слов'янській культурі дуже популярними були перекази про богатирів, в західноєвропейській - богів, а потім лицарів, в українській культурі, починаючи з XVI-XVII ст., ці образи уособлювало козацтво. Нас же цікавлять саме архаїчні образи богатирів, які складають базис архетипних уявлень про героїчну поведінку.

Образ богатиря теж мав свій розвиток $\mathrm{i}$ не залишався статичним протягом століть. Найдавніші уявлення про героя включали такі риси, як: здатність підкорювати сили природи, добре полювати і навіть чаклувати, тобто перекидатися на різних звірів. Такий архетип є відображенням архаїчного тотемізму, коли люди не відділяли себе від тваринного світу і вважали, о походять від певних тварин. Здатність до магічних дій є свідченням домінуючого міфологічного мислення. Також герої того часу більш агресивні, не захищають, а скоріше нападають першими, захоплюючи інші землі. У давніх слов'ян найвідомішим з таких героїв був Вольга (Волх) Святославич. Для підкреслення вищості над звичайними людьми часто застосовувався прийом гіперболізації - богатирям приписувалася надзвичайна сила та навіть величезний зріст.

Це цілком характерно для міфологічного мислення, для якого не існують заборони щодо реалістичності описів, межа між правдою і вигадкою часто не існує. Але головним $є$ 
наявність надзвичайної фізичної сили. В принципі, це цілком логічно, оскільки героїчна дія - це вияв активності фізично слабка людина не здатна ефективно діяти. Але цей архаїчний прийом уяви не можна вважати пережитком минулого, оскільки навіть в сприйнятті сучасної, освіченої людини часто перебільшуються особистісні якості героїв. Так, в народних оповідях про радянського розвідника Миколу Кузнєцова йому приписувалася надзвичайна сміливість, начебто він невразливий до кулі і знешкодив тисячу німців, хоча насправді він ліквідував всього 11 німецьких офіцерів.

На нашу думку, подібна гіперболізація $\epsilon$ свідченням того, що у сприйманні подвигу і образу Героя в цілому люди часто поєднують правдиву інформацію і свої очікування від цієї людини, часто даючи волю несвідомому, яке мислить в категоріях міфологічних.

Другою характерною ознакою протогероїв $є$ те, що в них вкладаються риси ментальності певного етносу. Цей факт детально описаний в аналізі епосу В. Я. Проппа. Можливо, таким способом кожен етнос прагне зберегти духовну спадщину. Передати нащадкам етнічні ідеали. Тобто образ Героя виконує виховну функцію. До речі, сучасні герої використовуються провладними верствами суспільства 3 тією ж метою. Для цього навіть створюють штучних героїв, приховуючи дискредитуючи факти їх біографії або викривлюючи істинні мотиви їх дій.

3 часом в народному епосі риси архети- пу Героя ставали більш диференційованими, в них окреслювалися характеристики звичайної людини. Уособленням такого образу в слов'янському епосі є Садко. В ньому простежуються ті ж звичні видатні фізичні дані, здатність до перевтілення і надзвичайні здібності (наприклад, можливість дихати під водою), що $є$ відлунням міфологічного мислення, але в той же час в його образі з'являються досить реалістичні деталі. Наприклад, він має музичні здібності, це людина всебічно розвинута, оскільки в здійсненні подвигу використовується вже не сліпа сила, а «хитрість-мудрість». Також у героїв 3'являються людські слабкості схильність до зловживання алкоголем, хитрість, нетерпимість до насмішок, оскільки його можна спровокувати на нерозсудливі дії, насміхаючись над ним.

Ще одна характерна особливість, яка простежується в описі епічних героїв - скромність. Вірогідно, у слов'ян засуджувалися вихваляння своїми досягненнями. Справжній Герой не буде навіть говорити про здійсненні подвиги, хіба що тоді, коли хоче відновити справедливість. Можливе пояснення такої вимоги до героя полягає в тому, що істинний подвиг в сприйнятті людей - це альтруїстичний вчинок, а вихваляння демонструє егоїстичну мотивацію - людина здійснила цей вчинок не заради допомоги, а заради власної слави, користі, тому це одразу девальвує цінність вчинку в очах соціуму.

В деяких випадках багатирі демонстру- 
ють аскетизм - у них немає багатства, великої сім'ї, навіть власного дому, вони не захоплюють трофеї у битвах або одразу ж їх роздають. Такий аскетизм був властивий майже всім народним образам богатирів - Іллі Муромцю, Добрині, Дунаю, Святогору. Тому, мабуть образ Альоши Поповича, який походив з багатої сім'ї і полюбляв розкоші, сприймається дещо скептично і не користується народною пошаною.

Ця архетипна ознака пізніше перейшла в традиції козацтва, ідеалом якого було презирливе ставлення до фізичного комфорту і статків. Справжній козак, особливо на початку зародження цього явища, не повинен був мати матеріальні ресурси, які б стримували його свободу пересування. Справжньому козаку не потрібно було нічого втрачати, крім власної голови.

В архетипі Героя в слов'янському епосі важливою $є$ також гендерна ознака. Вони в переважній більшості - чоловіки, але в той же час $\epsilon$ і жінки, які можуть битися нарівні з чоловіками. Як зазначає О.С. Орлов, це свідчить про наявність певних суспільних прав у жінок, що взагалі неможливе для західноєвропейської традиції, де жінок-лицарів не було взагалі. А поодинокий приклад Жани Д’Арк мав негативний фінал. Але в суто науковому значенні за класичним описом К. Г. Юнга архетип Героя належить до чоловічої статі, навіть граматично це слова чоловічого роду, оскільки повністю уособлює маскулінні риси, ідеал чолові- ка-захисника. Ця роль в традиційному суспільстві слов'ян жінці не приписувалася, хоча суворої заборони не мала, але в більш ранній період були вірогідними і санкції. Відголоском цього є билина про Дуная, який вбив свою дружину за те, що вона краще за нього стріляла з лука.

Іще одне цікаве спів падіння з сучасними психологічним теоріями полягає в тому, що образу Героя у слов'ян характерний комплекс неповноцінності в тому класичному вигляді, який описаний в теорії А. Адлера. Він описує 2 основних джерела формування комплексу - фізичні вади і результат неправильного стилю виховання. Дуже часто в епосі герої на початку свого життєвого шляху є хворими (Ілля Муромець) або соціальні вигнанці, сироти (Дунай, Добриня, Святогор, Потик). Потім герої долають свій фізичний або моральний недолік і здійснюють подвиг. Цей сюжет майстерно підмічає науково доведені закономірності в становленні вольових особистостей.

Оскільки виховання в надмірно сприятливих умовах не розвиває належним чином вольові якості. Людина за відсутності розумних перешкод не потребує розвитку вольової сфери заради виживання, тому вихідці з заможних верств населення серед слов'янських богатирів є рідкістю. Прикладом такого персонажу є Альоша Попович, але і популярність його як епічного Героя невелика.

Також етнічною особливістю архетипу 
Героя у слов'ян є його близькість до образу звичайної людини. Він не ідеалізований, як герої грецьких міфів (Геракл, Одісей), а мають свої вади і характерні риси, це доводить, що вони мали реальних прототипів, образи яких народна традиція зберегла у відносній недоторканості. Наприклад, Святогор має великий зріст і страшну силу, Альоша Попович сміливий і необачний. Він уособлює образ молодого Героя. Ілля Муромець це образ досвідченого і мудрого воїна, який не може похизуватись силою молодих, але перемагає суперників своєю мудрістю, досвідом.

Також окремо розглядається життєвих шлях Героя, його життєвий сценарій. В слов'янській культурі в сценарій обов'язково повинні бути включений елемент страждань і подолання певних слабкостей, власних вад i недоліків і тільки після цього виникають зовнішні перешкоди у вигляді різноманітних випробувань. Як правило, це не тільки випробування фізичної сили, але й оцінка моральних та інтелектуальних якостей Героя. У нас $\epsilon$ припущення, що цей сценарій закладається в ранньому дитинстві у певних особистостей, які в певному сенсі «приречені» бути героями, в них немає іншого шляху, і вони це розуміють ще задовго до скоєння подвигу.

Важливою відмінністю від інших культур є освіченість героїв слов'янського епосу. Тобто трюїзм «сила $\epsilon$, а розуму не треба» не знаходить свого підтвердження. Більшість руських богатирів були освіченими і мудрими, «воювали хитрістю-мудрістю». Особливо відрізнявся цим найпопулярніший Герой Ілля Муромець. Він ніколи не перемагав виключно силовими засобами. Це наголошує на необхідності побудови стратегії і тактики боротьби, в непрямому сенсі пропагує освіченість, ерудованість, компетентність у обраній діяльності.

В слов'янській традиції мало поважають необачних героїв, які сліпо кидаються назустріч загибелі, виграє лише дисциплінований, поміркований, обережний Герой. Міфологічні рудименти у переказах про богатирів мають архетипну рису наївного оптимізму герой не повинен загинути, він завжди виграє. Виключенням $\epsilon$ не дуже популярні персонажі - Святогор і Дунай, які гинуть як раз через свою необачність і гарячкуватість. Єдине, що може зломити волю епічного Героя - усвідомлення своєї непотрібності, непричетність до справ захисту рідної землі. Така невразливість слугує підвищенню рівня оптимізму в суспільстві, несе ідею незламності та безперервності існування соціуму, коли звичайна людина вважає місію нездоланою, образ Героя вселяє надію на подолання труднощів, оскільки є прикладом надзвичайної вольової і моральної поведінки.

Останньою і узагальнюючою характеристикою архетипного образу Героя є мотиваційна складова їх дій. На відміну від міфічних персонажів західноєвропейського епосу та авантюристичних східних персонажів, вони не здійснюють подвиг заради самого подвигу, в 
пошуках слави, а в переважній більшості слугують людям, тобто мають альтруїстичні мотиви допомоги ближньому. Образ лицаря, наприклад, включає в себе основний мотив служіння Прекрасній дамі або монарху, який править в його країні. Тобто часто їх мотиви дещо егоїстичні. В той же час, слов'янська традиція засуджує егоїстичні мотиви, визначаючи основною функцією Героя захист інтересів людей, які є його земляками. У загальному сенсі вони служать Батьківщині.

Таким чином, на основні проведеного аналізу культурних традицій і уявлень можна скласти узагальнений перелік рис архетипу Героя у порівнянні із західноєвропейською традицією, який приведений нижче.

Цей архаїчний мотив дуже вдало використовувався в процесі патріотичного вихо-

вання молоді в першій половині XX ст. в СРСР. I ефективність виховного впливу була дуже висока, оскільки експлуатувались саме несвідомі установки, недоліком цього процесу біло те, що образ Батьківщини часто підмінявся конкретними особистостями вождів, розчарування в яких призводило до генералізації негативної установки і на Батьківщину взагалі. Хоча, як було зазначено нами вище, Герої повинні дотримуватися автономії від влади, тому в суспільствах, де влада не взаємодіє 3 ними верствами населення, експлуатує їх, цей пункт особливо важливий і надає Герою привабливих для великих суспільних груп, що підвищує авторитет Героя.

Цей патріотичний мотив проявляється і в тому, що в епосі герой повинен обов'язково проявити не тільки сміливість, але й моральну

Таблиия 1.

\section{Порівняльний аналіз базових рис образу героя в західноєвропейській і слов'янсь-} кий традиції

\begin{tabular}{|c|c|c|}
\hline & Західноєвропейська культура & Слов’янська культура \\
\hline Спільні риси & \multicolumn{2}{|c|}{$\begin{array}{l}\text { Гіперболізація фізичних даних Героя } \\
\text { Долання внутрішніх слабкостей або фізичних вад } \\
\text { Обов’язкова перемога над ворогами, успіх у справі } \\
\text { Сміливість, рішучість і видатні вольові якості } \\
\text { Чоловіча стать як уособлення патріархальності суспільства }\end{array}$} \\
\hline Відмінні риси & $\begin{array}{l}\text { 1.Служіння богам або монархам } \\
\text { 2. Благородне походження } \\
\text { 3. ідеалізований образ } \\
\text { «суперлюдини» практично без не- } \\
\text { доліків } \\
\text { 4. Мотиви здійснення подвигу за- } \\
\text { ради слави або переходу на інший } \\
\text { рівень існування } \\
\text { 5. Одноосібне здійснення подвигу }\end{array}$ & $\begin{array}{l}\text { 1.Автономія від влади, служін- } \\
\text { ня народу } \\
\text { 2. Походження з бідних верств } \\
\text { населення } \\
\text { 3. Герой має недоліки і унікаль- } \\
\text { ні особистісні риси, як у зви- } \\
\text { чайної людини } \\
\text { 4. Здійснення подвигу заради } \\
\text { рятування Батьківщини від во- } \\
\text { рогів } \\
\text { 5. Співробітництво з іншими } \\
\text { богатирями }\end{array}$ \\
\hline
\end{tabular}


чистоту характеру. Характерним для героїв епосу є те, що вони не повинні бути при владі, часто вони знаходяться в опозиції до неї і допомагають не монарху, а всьому народу. Навіть походження більшості Героїв переважно 3 бідних верств населення, а до вихідців з багатих сімей (як от до Альоші Поповича) ставлення дещо презирливе. В слов'янських билинах князі і царі зображуються часто в гротескній формі, з елементами сатири й іронії. До речі, ті ж самі мотиви простежуються і в західноєвропейській фольклористиці, наприклад, Геракл теж служив не дуже сміливому, жадібному та нерозумному царю Єврисфею.

Таким чином ми підтвердили наше гіпотезу про існування культурних відмінностей в архетип них образах Героїв у слов'янській та західноєвропейській традиціях. Були виділені риси героїв, що уособлюють ідеальні особистісні характеристики чоловіка в даній культуpi. Цей образ слугує орієнтиром у виховному процесі молоді і базується на складових, які в основному залишаються неусвідомленими i мають значну стабільність у часі. Але ретроспективний аналіз показав існування і певної динаміки в зміні цих складових, які здійснюються під впливом соціально-культурних змін. На жаль недостатньо дослідженими залишаються питання рівня впливу цього архетипного образу на героїчну поведінку особистості в сучасному світі і співвідношення свідомих та несвідомих компонентів поведінки.

\section{Перелік використаних джерел:}

1. Кэмпбелл Дж. Тысячеликий герой. / Дж. Кэмпбелл. М.: Рефл-бук АСТ, 1997. - 465 с.

2. Орлов А. С., Пропп В.Я. Героическая тема в русском фольклоре. / сост. И отв. Редактор О.А.Платонов. - М.: Институт русско цивилизации, 2015.- 864 с.

3.Суравнёва И. М. Героизм как социальный феномен: специальность - 09.00.11 - социальная философия диссертация на соискание ученой степени кандидата философских наук. - Тверь - 2006. - 188 с.

4. Юнг К. Г. Человек и его символы. / К.Г..Юнг.- М.: EKCMO., 2016.- 352 c.

\section{References (Transsliteration):}

1. Kempbell Dzh. Tyisyachelikiy geroy. / Dzh. Kempbell. M.: Refl-buk AST, 1997. - 465 s.

2. Orlov A. S., Propp V.Ya. Geroicheskaya tema v russkom folklore. / sost. I otv. Redaktor O.A.Platonov. - M.: Institut russko tsivilizatsii, 2015.- $864 \mathrm{~s}$.

3. Suravnyova I. M. Geroizm kak sotsialnyiy fenomen: spetsialnost - 09.00.11 - sotsialnaya filosofiya dissertatsiya na soiskanie uchenoy stepeni kandidata filosofskih nauk. Tver $-2006 .-188 \mathrm{~s}$.

4. Yung K. G. Chelovek i ego simvolyi. / K.G..Yung.- M.: EKSMO., 2016.- $352 \mathrm{~s}$.

\section{Vasuk Katerina}

PhD, lecturer of the Department of psychology of Vasil Stus Donetsk national university, Vinnitsa (Ukraine)

\section{THE ETHNIC PECULIARITIES OF THE HEROE'S ARCHETYPE IN THE SLAVIC CULTURE}

\section{ABSTRACT}

In the article we have realized theoretical analysis investigations and empirical researching the Hero in Slavic culture. We compared it with stories in West Europe, analyzed the differences 
in the filling of the image of Hero in the archetypical stories of different cultures.

On the base of theoretical analysis of the theories about problem we have defined, that the Hero is specifically standard of positive, prosocial behavior. We must have to aim to the standard of behavior.

As the main objective of the study was revealing specifically features of the Hero in the Slavic culture. They determine modern perception and evaluation of person's behavior as heroic. As the method of investigation, we used the meaningful analysis of ancient Slavic stories about heroes, including content analysis, as well as a comparative analysis of the selected behavioral patterns and personality traits in the image of the Hero with personal features and features of exploits of modern heroes. Image of Hero is power mean of education for new generation. That's why the image was formed for interest of the ruling strata of the population. Also, there are two types of heroes, they are local and social. Social Hero is retrospective definition. Popular personals pretend this role.

The reasons for this are not always in original exploit, these personals are carriers of real or imagined personality traits that are recognized in the given social group as ideal. For Slavic culture is expression of archetype Hero as image "bohatir", after "kozak" in Ukrainian culture. In the West Europe's culture, he is knight. As personal features, which are basic orientin in this archetype, we used asceticism, modesty, a pro- nounced sense of justice and courage. But Slavic heroes have negative features of character as ordinary people. The image of Hero has an inferiority complex in the classical form described by A. Adler. He described two main the source of the inferiority complex formation is physical defects and the result of incorrect education, that is, the way to heroism lies through overcoming this complex.

Retrospective analyses showed being dynamics in the change of these components, which are carried out under the influence of sociocultural changes. Questions about level influence this archetype image to heroic behavior of the person, ratio of conscious and unconscious components of behavior in modern world are not researched.

Key words: archetype, cultural tradition, exploit, Hero.

\section{Васюк Екатерина Николаевна}

Кандидат психологических наук, доцент, дочент кафедры психологии Донецкого начионального университета имени Васыля Стуса, г. Винница (Украина)

\section{ЭТНИЧЕСКИЕ ОСОБЕННОСТИ АРХЕТИПА ГЕРОЯ В СЛАВЯНСКОЙ КУЛЬТУРЕ}

Аннотация. В статье осуществлен теоретический анализ подходов и эмпирическое изучение образа Героя в славянской культурной традиции. Осуществлено сравнение его с западноевропейскими сюжетами, проанализированы отличия в наполнении образа Героя в архетипных сюжетах разных культур. 
На основе теоретического анализа подходов к проблеме определено, что Герой своеобразный эталон позитивного, социально одобряемого поведения, к которому нужно стремиться просоциально направленным людям или образцы поведения. В качестве основный цели исследования было выявление специфических для славянской культуры психологических черт Героев, которые обуславливают современное восприятие и оценку поведения личности как героического.

В качестве методов исследования использовался содержательный анализ древнеславянских дум и былин о героях, в том числе и контент-анализ, а также сравнительный анализ выделенных поведенческих паттернов и личностных черт в образе Героя с чертами личности и особенностями подвигов современных героев. Установлено, что образ Героя является мощным воспитательным средством для молодого поколения, поэтому его часто искусственно формируют в интересах правящих слоев населения. Также выделены два типа Героя - локальный и общесоциальный. Общесоциальный Герой - это понятие ретроспективное. На эту роль претендуют личности, которые имеют общенациональное признание. Причины этого не всегда в исключительности их подвига, а в том, что эти личности есть носителями действительных или воображаемых черт личности, которые в данной социальной группе признаются за идеал.

Для славянской культурной традиции характерно выражение архетипа Героя в образе богатыря, позднее украинская культура выделяла казака. В западноевропейской чаще это рыцарь. В качестве лавных личностных черт, которые являются базовыми ориентирами в этом архетипе есть такие: аскетизм, скромность, выраженное чувство справедливости и смелость. Но в отличие от западноевропеской традиции, славянские Герои имеют негативные черты характера, что приближает их к обычным людям. Образу Героя у славян характерен комплекс неполноценности в том классическом виде, который описан у А. Адлера. он описывает2 основных источника формирования комплекса неполноценности - физические недостатки и результат неправильного воспитания, то есть путь к героизму лежит через преодоление этого комплекса.

Ретроспективный анализ показал существование и определенной динамики в изменении этих составляющих, которые осуществляются под влиянием социально-культурных изменений. Недостаточно исследованными остаются вопросы уровня влияния этого архетипного образа на героическое поведения личности в современном мире и соотношение сознательных и бессознательных компонентов поведения.

Ключевые слова: архетип, Герой, культурная традиция, подвиг.

Дата отримання статті: 04.04.2018 Дата рекомендації до друку: 15.04.2018 Дата оприлюднення: 19.04.2018 